\title{
Implementation of Standard Specifications on Secondary School Facilities in Etsako West Local Government Area, Edo State
}

\author{
Ugiomoh, Isoa Charity Ph.D \\ Department of Educational Management, University of Port Harcourt, Nigeria \\ E-mail: ugiomohcharity@yahoo.com \\ Ememe, Ogbonna Nwuju Ph.D \\ Department of Educational Management, University of Port Harcourt, Nigeria \\ E-mail: ememeon@yahoo.co.uk \\ Obike, Comfort Nnennaya Ph.D \\ Department of Educational Foundations, University of Nigeria, Nsukka \\ E-mail: mummyobike@gmail.com
}

Accepted: Feb 16, 2013 Published: March 03, 2013

Doi:10.5296/ijhrs.v3i4.4365 URL: http://dx.doi.org/10.5296/ijhrs.v3i4.4365

\begin{abstract}
This study investigated the extent of the implementation of standard specifications on secondary schools facilities in Etsako West Local Government Area, Edo State. It was a descriptive survey. A sample of 135 teachers emerged from a population of 432 through stratified random representation. A 2-part, 18-item, 4-point scale instrument known as standard specification questionnaire (SSQ) was used to collect data for answering 2 research questions. SSQ was validated by a team of experts. Test-retest reliability was established at an r-0.85. Findings revealed among others that lack of funds posed a major problem in the implementation of standard specification on secondary schools' facilities on public/rural schools. It was concluded that if education is well funded, enough specified facilities provided, it will go a long way in breeding intellectuals who are morally, culturally, socially, and intellectually balanced to give society the necessary level of economic development. It was recommended among others that classrooms must be spacious enough to promote adequate interdisciplinary learning.
\end{abstract}

Key words: Implementation, Standard Specifications, Secondary, School, Facilities.

\section{Background of the Study:}

Secondary education in Nigeria has particularly been demanded for right from its inception as an acceptable educational qualification for white collar jobs or preparation for 
useful living in Nigeria and as a sure way to attaining higher education in Nigeria has led to some expansion and development geared towards making secondary education more functional and relevant to the emerging needs and aspirations of Nigerian society and at the same time satisfying the increasing demand for it. Hence, the government took a bold step in taking over schools in the '70s' and such, education became politicized, schools where re-structured and re-organized. These arrangements where geared towards giving education positive developments yet serious problems arose ranging from an upsurge in students' enrolment and over used/stretched physical facilities in schools. Hence, the secondary education in Nigeria has been bedeviled by low transition rate, over-crowed and over-used classroom furniture.

To have a creative school, there is the need to involve an educator, an economist, a quantity surveyor, a designer while planning a school plant. The educator possesses the capacity to determine the building and material needs of the school, the architects may help to translate these building needs as conceived by the educator into practical terms through designs and specifications. Hence, Enaohwo (1990:248) stipulates "planners have to consult with as many people and agencies as possible before providing resource programs for implementation in schools". Since material resources have to do with school plants, there is the need for a well planned and organized school plants to make for effective administration. If there is shortage of accommodation, furniture, equipment or other material resources, this can affect the productivity of teachers, administrator-teacher relationship and even administrator-pupil relationship. There is the need not only to plan and organize the school but to use standard specifications. There should be symptoms of changing trends in students' learning hence no building should undergo greater change in recent years than the school building.

Accommodation, an ideal teacher/pupil relationship, a conducive environment, adequate resource material for learning. "school programs must be implemented, teachers trained in required quantity and school buildings and equipment provided to meet educational specifications and made functional" posits Agabi (1999). It therefore becomes imperative that in order to attain set educational objectives of any community, there should be an implementation of standard specifications in order to avoid a short-fall or an undervalued expectation by parents and recipients of education.

When facilities are provided according to standards, they provide facilitating and stimulating environment for effective teaching and learning in schools. School plant like other physical facilities require a constant program of maintenance since they exist to facilitate instructional learning. Most of these maintenance works hardly take place because of socio-economic problems. It should be noted that the equipment that wears out must be replaced, mortar that loosens must be repaired. Roofs leak must be repaired. Most maintenance jobs require skilled craftsmen including plumbers, painters, electricians, masons, roofers and many others.

The concept of standard specifications embraces size, shape, number and quality of education space/ facilities. Secondary schools should be provided with minimum school facilities, which must reflect its curriculum. Planning these facilities must involve an 
estimation of students' population and the existing ones evaluated bearing in mind the needs of the school as stated by educational aims and objectives. It therefore behoves the school administrators, the government and various communities to fashion out ways of having standards in school, bearing in mind that schools do not exist alone, students, teachers, administrators inhabit them during the day. If standards are not implemented I schools, the students in the local government area will not benefit from learning outcomes and as such, there are bound to be problems in their educational achievements.

\section{Statement of the Problem:}

The content of the secondary education has in recent years been diversified. These diversifications are in the introduction of the Universal Primary Education (UPE) in 1976 and in the 80's with the introduction of the 6-3-3-4 system of education. With an upsurge in transition rate of secondary school enrolment, the problems that bother the researcher is whether facilities are provided in their right size and shape, whether these facilities are available in all the secondary schools for the implementation of schools' programs and whether they are adequate enough to meet teachers' efficiency in the dispensation of their duties and are they maintained. The researcher is equally bothered whether they are maintained.

\section{Purpose of the Study:}

From the problems identified, the purpose of the study therefore was to:

i. Determine the extent of implementation of the physical facilities specifications in schools. The facilities are classrooms, furniture, libraries, laboratories, workshops, computer, chalkboards, audio visual aids and school examination hall.

ii. To find out the maintenance practices adopted on facilities in the secondary schools.

\section{Research Question:}

The following questions guided the researcher in this study.

i. What is the extent of implementation of standard specifications on physical facilities for teaching and learning in secondary schools in Etsako West Local Government Area Edo State?

ii. What maintenance practices are adopted on secondary schools' facilities?

iii. What are the problems militating against the implementation of standard specification on secondary school facilities?

\section{Methodology:}

This study adopted a descriptive survey design to find out the extent of implementation of standard specification on secondary schools facilities in public and private schools.

All the 432, made up of 232 teachers from public schools and 200 from private secondary schools made up the population. A total of 135 teachers representing $31 \%$ of the population was selected through stratified random representation.

A 2 part, 18-item, 4-point scale instrument known as standard specification Questionnaire (SSQ) was used to generate data for answering 2 research questions and testing 2 null 
hypotheses.

Content and face validity of the instrument were determine by experts in educational management Test-retest method was used to establish the reliability co-efficient using Parsons Product moment correlation at 0.85 .

The instruments were distributed and retrieved by the researchers. Means and t-test were used to answer the RQ and test the will hypotheses at 0.05 level of significance.

RQ 1: What is the extent of implementation of standard specifications on the following: class size, furniture per child and number of classrooms in public/private schools.

Table 1: Extent of implementation of standard specifications.

\begin{tabular}{|l|l|l|l|l|l|l|l|}
\hline $\begin{array}{l}\text { School } \\
\text { Type }\end{array}$ & $\begin{array}{l}\text { Maximum } \\
\text { No. } \\
\text { students }\end{array}$ & $\begin{array}{l}\text { Average Class } \\
\text { size }\end{array}$ & $\begin{array}{l}\text { Furniture Per } \\
\text { Child }\end{array}$ & \multicolumn{2}{l|}{ No. of Classroom } \\
\hline & In a class & Mean & SD & Mean & SD & Mean & SD \\
\hline Public & 40 & 53.66 & 23.78 & .72 & .97 & 10.66 & 8.55 \\
\hline Private & 40 & 44.70 & 21.74 & .43 & .21 & 9.88 & 4.66 \\
\hline
\end{tabular}

With maximum number of 40 in the class in both private and public school, average class size for the public 53.66, furniture per child 0.72, number of classroom 10.66. For the private schools, average class size 47.70 , furniture per child 0.43 , number of classrooms 9.88 . This shows that private schools are competing highly with public secondary schools in terms of number of students, classrooms, they lag behind in the provision of furniture.

RQ.2: What maintenance practices are adopted on secondary facilities?

For a proper and continuous use of these facilities they must be properly maintained in order to achieve the goals of the recipients of education. This question investigated how these scare facilities are maintained in public/private schools. The data answering this question is presented in page 7 .

\begin{tabular}{|l|l|l|l|l|}
\hline Maintenance Practices & \multicolumn{2}{|l|}{ Public Secondary Schools } & \multicolumn{2}{l|}{ Private Secondary Schools } \\
\hline & Mean & SD & Mean & SD \\
\hline Routine Maintenance & 2.05 & 2.01 & 2.34 & .89 \\
\hline Curative Maintenance & 2.70 & .78 & 2.59 & .53 \\
\hline Ad-ho Maintenance & 2.21 & .68 & 2.43 & .76 \\
\hline No Maintenance & 1.88 & .64 & 1.90 & .79 \\
\hline
\end{tabular}

As the table indicates, the analysis of the data shows that all of the available facilities, the maintenance practice on them is mainly the curative maintenance practice. This is because the mean for curative maintenance practice exceeds 2.50 as the public schools has a mean of 2.70 while the private schools has a mean of 2.59 . The evidence is that facilities in both public and private schools are not regularly maintained. 
RQ 3: What are the problems militating against the implementation of standard specification on secondary school facilities?

Table 3: Mean opinion of principals and teachers on the problems militating against implementation standard specification on facilities.

\begin{tabular}{|c|c|c|c|c|}
\hline \multirow[t]{2}{*}{ Problems } & \multicolumn{2}{|c|}{ Public Schools } & \multicolumn{2}{|c|}{ Private Schools } \\
\hline & Mean & SD & Mean & SD \\
\hline $\begin{array}{l}\text { Insufficient fund for the } \\
\text { provision of facilities }\end{array}$ & 3.44 & .61 & 2.59 & 1.11 \\
\hline $\begin{array}{l}\text { Lack of electricity supply to } \\
\text { schools }\end{array}$ & 2.20 & 1.21 & 2.19 & 1.22 \\
\hline lack of storage facilities & 2.64 & 1.20 & 2.44 & 1.12 \\
\hline Lack of storage space & 2.14 & 1.15 & 1.81 & 1.05 \\
\hline $\begin{array}{l}\text { Lack of facilities maintenance } \\
\text { workshop }\end{array}$ & 2.75 & .99 & 2.49 & 1.21 \\
\hline
\end{tabular}

The above table indicates that insufficient funds for the provision of facilities pooled 3.44 and 2.59 for both public and private schools. Lack of storage facilities, and facilities maintenance workshop were problems only in public schools, whereas in private schools they did not constitute problem. Lack of electricity supply constituted a problem both in public and private schools.

\section{Summary of Findings}

a. Average class size for both public and private secondary schools exceeded the stipulated number of students as approved by the National Policy on Education. Federal and state Ministries of Educations and UNESCO, However, students are more in the public than in the private schools.

b. The urban and rural schools exceeded the maximum number of student in the class as approved by the National Policy on Education, Federal and state Ministries of Education and UNESCO. A high average class size was recorded in the urban schools than the rural schools.

c. There are more furniture in the urban schools than in the rural schools. It is pertinent to note here that most schools in rural areas have still not conformed with the approved 4 seater bench and tables but still have their normal table and chair per student. However, following the result still, not every child has a chair and a table. Moreso, most of the public schools still maintain the one table and chair per student.

d. The major factor militating against implementation of standard specifications in both public and private schools is insufficient fund for the provision of facilities.

The maintenance practice carried out in the public/private urban and rural schools is mainly the curative type. 


\section{Discussion of Results}

The findings in research question 1 is supported by the recommendation of UNESCO (1984) that 40 students and 25, giving an average of 35 be accommodated in a floor space of 0.81 sq meter. Additionally, Urevbu (1991) stated that the provision of seats and desks should take into consideration the age, size and height of the pupils. Similarly, Gbamanja (1991) maintained that what he hears he forgets and what he, does he remembers. Commenting on the importance of standard specification, Singh (1996) noted that IQ is about $40 \%$ a matter of environment.

In RQ2, Campbell (1977) emphasized that when equipment wears, they must be replaced, He suggested that maintenance must be are by skillful craftsmen including plumbers, painters, electricians, masons and roofers.

Corroborating Mgbodile (2003) stated that school plant maintenance is the keeping of school building and equipment in as near their original conditions as possible. He emphasized that efforts be made to maintain wholeness and efficiency of the equipment, building and other facilities.

The issues raised in RQ3 are corroborated in the words of Daini (1999:73) where he opined that "there are in incessant cases of wastages, mismanagement and diversion of funds at the detriment implementation standard specification in schools.

\section{Conclusions}

The greatest legacy a child would have from his parents in particular and the nation in general is education. It is surely an investment to man. Among other things, if quality education is given to the recipients, higher levels of attainment would be achieved and the education industry would attract high rate of recognition.

Environment for learning must be stable and should there be positive changes, it then shows that meaningful learning is taking place. Such changes must mean that classrooms are adequate and reflect the standard specified. Class size must the stipulated number, every child should have the opportunity of owing a chair and a table and be comfortable during lessons.

Facilities need to be maintained regularly to ensure a longer life span. If facilities are well secured, vandalism by the community will not occur. Enough funds are indispensable if standard specifications are to be implemented.

\section{Recommendations}

1. A school whose population is up to 1,000 students should have 30 classrooms while schools with up to 800 students should have 27 number of classrooms so as to reduce class size.

2. Classrooms must be spacious enough to promote a hands-on inter-disciplinary learning. A variety of spaces within the classroom support teacher/student relationship.

3. School desks and chairs should be provided for every child so as to achieve a positive learning outcome on the children. 
4. Facilities provided in schools should be adequate enough to cater for the enrollment in the school. While implementing schools' facilities, they must be in the standard specified so that the goals of education would be achieved.

5. Grants to education must meet with the required percentage as stipulated by UNESCO.

6. Schools should employ security agents to help take care of facilities to prevent vandalisation.

\section{References}

Agabi, O.G (1999). Introducing Educational Planning. Port Harcourt: Springfield Publishers.

Campbell, C (1977). Introduction to Educational Administration. Toronto Allyn and Bacon.

Daini, A. B. (1999). Towards Effective Educational Planning in the $21^{\text {st }}$ Century. A planners Perception. Journal of Educational Focus 2(1).

Enaowho, J. O. (1990). Economics of Eduaction: The Nigerian Experience Owerri: New African Publishing.

Gbamanja, S. P. T (1991). Modern Methods in Science Education in Africa. Port Harcourt: Totan Publishers.

Mgbodile, T. O (2003). Fundamentals in Educational Administration and Planning. Enugu: Magnet Business Enterprises.

Singh, B. R. (1996). The Genetic Environmental Influences on Individual Cognitive Functioning and I.Q. Journal of Educational Studies Vol 22(1).

UNESCO (1984). Planning Team. Paris: UNESCO Press.Urevba, A. O. (1991). New Principals and Practice of Education in Nigeria. London: Julard Publishers. 